\title{
Studi evaluasi penerapan Community Based Tourism (CBT) sebagai pendukung agrowisata berkelanjutan
}

\section{The evaluation study of implementation as Community Based Tourism (CBT) on supporting sustainable agritourism}

\author{
Sri Endah Nurhidayati \\ Program Studi D3 Kepariwisataa/Bina Wisata, Fakultas Vokasi, Universitas Airlangga \\ Kampus B Jalan Srikana 65, Surabaya, Indonesia \\ E-mail: sriendahnurhidayati2015@gmail.com
}

\begin{abstract}
The role of government in the development of Community Based Tourism (CBT) is critically important to strengthen communities around tourism destination. Government has significant role to ensure that the community has access, opportunity and important power in the development of tourism. The objectives of this research are: (1) describe the government's perception of the Community Based Tourism (CBT) development, (2) identify government policies to support the Community Based Tourism (CBT) implementation in Batu City, East Java, and (3) describe the constraints that occur in the implementation of Community based Tourism (CBT) in Batu City, East Java. This study uses qualitative approach by analyzing critical reality that was constructed locally and specifically. The study conducted in Batu City, East Java. Perceptions of government on the implementation of community-based tourism reflected the mindset of the individual. Barriers to the implementation of community-based tourism development with regard to the internal aspects of the government are: the quality of human resources decision makers in the Batu Government did not possess educational background of tourism, government people were less creative in designing programs and somewhat forced, the lack of trust the government to local communities, government wass not able to map the condition social community related to the system's internal decision-making in the community that are less able to intervene in all components of society, a narrow understanding of CBT, yet solid government policy coordination between stakeholders. While the external barriers were lack of insight into the capabilities and limitations of the community in terms of tourism, community participation uneven, limited area of Batu, less technological mastery, and the effects of global warming are affecting the climate and cause decreased production and apples quality.
\end{abstract}

Keywords: agritourism, Community Based Tourism (CBT), sustainable agritourism

\begin{abstract}
Abstrak
Peran pemerintah dalam pengembangan Pariwisata Berbasis Masyarakat (CBT) sangat penting untuk memperkuat masyarakat di sekitar daerah tujuan wisata. Tujuan penelitian yang ingin dicapai adalah: (1) mendeskripsikan persepsi pemerintah dalam pengembangan CBT, (2) mengidentifikasi kebijakan pemerintah untuk mendukung implementasi CBT Masyarakat di Kota Batu, Jawa Timur, dan (3) menjelaskan kendala yang terjadi dalam pelaksanaan CBT di Kota Batu, Jawa Timur. Penelitian ini menggunakan pendekatan kualitatif dengan menganalisis realitas kritis, dan dibangun secara lokal dan spesifik. Lokasi penelitian terletak di Kota Batu, Jawa Timur. Penelitian ini menemukan bahwa pemerintah berperan penting dalam mengawasi pengembangan produk pariwisata, terutama desa wisata dan membantu mengembangkan serta promosi pasar. Hambatan pelaksanaan pembangunan pariwisata berbasis masyarakat berkaitan dengan aspek internal pemerintah: kualitas sumber daya manusia pengambil keputusan di pemerintah Batu tidak memiliki latar belakang pendidikan pariwisata, desain kurang kreatif, kurangnya kepercayaan pemerintah kepada masyarakat lokal, pemerintah tidak mampu memetakan kondisi komunitas sosial yang berhubungan dengan sistem internal pengambilan keputusan di masyarakat yang kurang mampu menjangkau semua komponen masyarakat, pemahaman sempit CBT, namun koordinasi kebijakan pemerintah yang solid antara para pemangku kepentingan. Sementara hambatan eksternal kurangnya wawasan kemampuan dan keterbatasan masyarakat dalam hal pariwisata, partisipasi masyarakat tidak merata, daerah terbatas Batu, kurang penguasaan teknologi, dan efek dari pemanasan global yang mempengaruhi iklim dan menyebabkan penurunan produksi dan kualitas apel.
\end{abstract}

Kata kunci: agrowisata, pariwisata berbasis komunitas (CBT), agrowisata berkelanjutan. 


\section{Pendahuluan}

Community Based Tourism (CBT) merupakan alternatif pengembangan pariwisata yang dianggap lebih menguntungkan masyarakat setempat dan menjamin keberlanjutan pariwisata. CBT juga terkait erat dengan perkembangan kebutuhan manusia untuk mengonsumsi jasa pariwisata yang telah memberikan peluang besar bagi perkembangan industri pariwisata. Berbagai jenis objek dan atraksi wisata berkembang seiring dengan perkembangan pariwisata global yang mengarah ke bentuk wisata alternatif, seperti wisata budaya, wisata alamiah, dan ekowisata. Salah satu aspek yang harus dipenuhi dalam pengembangan CBT adalah menitikberatkan pengembangannya pada masyarakat. Masyarakat menduduki posisi sebagai bagian integral yang ikut berperan serta, baik secara subjek maupun objek.

Pengembangan pariwisata berbasis mensyaratkan pendekatan partisipatif agar terbentuk kemitraan di antara stakeholder (Demartoto 2009:21). Pendekatan partisipatif membutuhkan koordinasi dan kerjasama serta peran yang berimbang antara berbagai unsur stakeholder termasuk pemerintah, swasta, dan masyarakat. Pengembangan CBT juga membutuhkan dukungan penuh dari pemerintah dari berbagai tingkatan mulai tingkat Desa hingga kabupaten/kota.

Peran pemerintah dalam pengembangan CBT sangat penting. Strategi yang dapat dilakukan antara lain dengan memperkuat komunitas di sekitar destinasi. Peran komunitas dalam pengembangan pariwisata sangat tergantung sejauh mana mereka memiliki kesempatan dan kekuatan (Beeton 2006:82). Pemerintah berperan dalam menjamin agar komunitas memiliki akses, kontrol, kesempatan dan kekuatan dalam pengembangan pariwisata melalui regulasi. Regulasi merupakan usaha pemerintah yang telah diberi kewenangan atau otoritas untuk mengatur aktivitas tertentu yang berada dalam wilayah yuridisnya yang berdampak pada meningkatnya akses, kontrol, kesempatan dan kekuatan komunitas. Pemerintah dapat memberlakukan aturan tertentu yang mendikte pihak lain untuk mendukung atau melaksanakan kebijakan pemerintah dalam pemberdayaan komunitas. Dalam kaitannya dengan pengembangan CBT regulasi merupakan alat bagi pemerintah dalam menjamin stakeholder pariwisata tetap berperilaku dalam koridor kebijakan pariwisata yang telah ditetapkan atau menuruti ketentuan yang sudah ditetapkan pemerintah (Pitana \& Diarta 2009:118).

Beberapa contoh kebijakan stretegis yang dilakukan pemerintah untuk mendukung pelaksanaan CBT antara lain yang dilakukan Pemerintah Malaysia di Lankawi melalui pengembangan akses ke pulau dengan membuka penerbangan domestik dan membentuk badan pengelola The Langkawi Development Authority (LADA) yang melibatkan segenap anggota masyarakat dalam bidang usaha dan pelaksanaan proyek. Pengembangan pariwisata di Seychelles ditandai dengan kebijakan pemerintah setempat yang membatasi kiprah pemodal luar. Masyarakat setempat diberdayakan dalam usaha-usaha kecil yang "tertutup" bagi pemodal luar atau hanya diperuntukkan bagi penduduk setempat, seperti usaha hotel kecil berkapasitas kurang dari 25 kamar, usaha persewaan kendaraan dan taksi (Warpani \& Warpani 2007:166). Tujuannya untuk melindungi dan memberdayakan masyarakat setempat. Pengembangan pariwisata diharapkan berdampak positif bagi kesejahteraan masyarakat di sekitar destinasi. Dengan demikian kebijakan yang dibuat pemerintah menjamin hak masyarakat. Kebijakan pemerintah yang dibuat tidak lepas dari persepsi pemegang keputusan. Pemerintah sebagai pihak yang memiliki kewenangan merancang kegiatan pembangunan memiliki keleluasaan untuk merancang sesuai dengan apa yang wawasan, pengetahuan dan hal-hal yang dipikirkan. Oleh karena itu persepsi memegang peran sangat penting sebagai dasar bagi aktifitas penyusunan program pembangunan.

Pendekatan adaptative menjadi dasar bagi timbulnya pendekatan pembangunan pariwisata alternatif yang lebih berpihak pada masyarakat bukan pemilik modal. Pengembangan pariwisata yang menggunakan pendekatan Community Based Tourism (CBT) lebih efektif sebagai alat menyejahterakan masyarakat lokal. Pendekatan CBT memiliki kelebihan karena menempatkan masyarakat lokal sebagai subjek pengembangan pariwisata, bukan sebagai objek. Dengan demikian, pengembangan agrowisata dengan pendekatan Community Based Tourism (CBT) merupakan alternatif 
untuk mengembangkan potensi pertanian lokal, meningkatkan kesejahteraan dan pemberdayaan masyarakat lokal.

Strategi pemberdayaan masyarakat dalam konsep Community Based Tourism dalam mencapai tujuan pemberdayaan, berbagai upaya dapat dilakukan melalui berbagai macam strategi. Salah satu strategi yang memungkinkan dalam pemberdayaan masyarakat adalah pengembangan pariwisata berbasis masyarakat yang secara konseptual memiliki ciri-ciri unik serta sejumlah karakter yang oleh Nasikun dalam hand out mata kuliah Strategi Pengembangan dan Pengelolaan Resort and Leisure Gumelar S. Sastrayuda (2010:3) dikemukakan sebagai berikut: (1) pariwisata berbasis komunitas/masyarakat memiliki ciri-ciri/karakter unik yaitu memiliki unit usaha kecil, secara ekologis aman, dan tidak banyak menimbulkan dampak negatif seperti yang dihasilkan oleh jenis pariwisata konvensional; (2) pariwisata berbasis komunitas berpeluang mengembangkan objek-objek dan atraksi-atraksi wisata berskala kecil dan dapat dikelola oleh komunitas-komunitas dan pengusaha-pengusaha lokal; dan (3) komunitas lokal berpeluang ikut menikmati keuntungan pariwisata.

Timothy (1999) secara khusus mencoba menelaah perencanaan partisipasi masyarakat di sekitar obyek wisata di Indonesia (Yogyakarta) dan menyimpulkan bahwa keterlibatan pelaku wisata dalam perencanaan pembangunan pariwisata di Yogyakarta masih rendah, karena tingkat keaktifan pelaku wisata sangat tergantung pada akses yang diberikan pemerintah. Dapat disimpulkan bahwa keterlibatan pelaku wisata di Yogyakarta sangat tergantung pada akses yang diberikan pemerintah. Berkaitan dengan pendekatan pariwisata berbasis masyarakat Tosun dan Timohty (2003:4-9) mengajukan beberapa proposisi tentang pentingnya peran komunitas: (1) menjamin masyarakat untuk memahami dan bekerjasama dalam pengembangan pariwisata (Broadbent 1988:139); (2) partisipasi komunitas (masyarakat) syarat bagi pengembangan pariwisata yang berkelanjutan (Murphy 1985, Inskeep 1991), dan mengurangi dampak negatif pariwisata (Pearce 1994, Gartner 1996); (3) partisipasi komunitas (masyarakat) dapat meningkatkan kepuasan wisatawan (D'Amore 1983:143); (4) partisipasi komunitas (masyarakat) membantu professional bidang pariwisata merancang perencanaan pariwisata yang lebih baik; (5) Partisipasi komunitas (masyarakat) ikut andil dalam mendistribusikan biaya dan keuntungan yang lebih adil kepada seluruh masyarakat (Eadington \& Smith 1992); (6) partisipasi komunitas (masyarakat) membantu mengakomodir kebutuhan local (Inskeep 1994, Garrod 2001); dan (7) Partisipasi komunitas (masyarakat) menguatkan proses demokrasi di daerah tujuan wisata.

Penelitian ini merumuskan permasalahan sebagai berikut (1) Bagaimana persepsi pemerintah Kota Batu tentang pengembangan Community Based Tourism (CBT), (2) Bagaimana kebijakan pemerintah Kota Batu untuk mendukung pelaksanaan Community Based Tourism (CBT), dan (3) Apa saja kendala-kendala yang terjadi dalam pelaksanaan Community Based Tourism (CBT) di Kota Batu.

\section{Metode Penelitian}

Penelitian ini menggunakan pendekatan kualitatif menggunakan analisis realitas kritis, serta dikonstruksi secara lokal dan spesifik (Denzin \& Lincoln 2009:135, Moleong 2005). Lokasi penelitian ditetapkan Kota Batu, Jawa Timur. Alasan dipilihnya lokasi penelitian di Kota Batu adalah karena Kota Batu mengembangkan sebagai kota tujuan wisata berbasis masyarakat. Kota Batu merupakan salah satu ikon pengembangan agrowisata berbasis masyarakat di Jawa Timur.

Unit analisis penelitian ini adalah individu dan institusi. Individu sebagai sasaran penelitian yaitu stakeholder yang terkait dengan pengembangan dan pelaksanaan community based tourism (CBT) seperti Kepala Desa, pejabat/staf di SKPD terkait, sedangkan sasaran berupa Institusi yaitu berkaitan dengan regulasi/kebijakan/program kerja terkait dengan pengembangan dan pelaksanaan community based tourism (CBT). Unit analisis Institusi adalah stakeholder terkait dengan permasalahan penelitian yaitu SKPD (Satuan Kerja Pemerintah Daerah) berupa Dinas/Instansi yang terkait dengan pengembangan CBT, Dinas Pariwisata sebagai menjadi SKPD teknis pariwisata, Bappeda sebagai SKPD perencana pembangunan, BPS sebagai pengelola/pusat data, dan Pemerintah Kecamatan/Desa sebagai instansi yang membawahi langsung objek agrowisata dan sarana-prasarana pendukungnya. 
Pengumpulan data primer dilakukan menggunakan wawancara mendalam dengan pedoman wawancara dan observasi. Pengumpulan data sekunder menggunakan data dari BPS, SKPD terkait dan Monografi Desa/Kelurahan dan kecamatan. Analisis data berupa kuantitatif menggunakan statistik deskriptif sedangkan data kualitatif akan dianalisis menggunakan analisis konten/isi dan interaktif (Miles \& Huberman 1992).

\section{Hasil Penelitian dan Pembahasan}

Pariwisata berbasis masyarakat merupakan terminologi yang sudah dikenal pemerintah kota Batu, namun secara eksplisit tidak disebutkan dalam dokumen pembangunan maupun program kerja yang ada di SKPD (pemerintah).

Menurut Elok dari Dinas Pariwisata dan Ekonomi Kreatif Kota Batu:

“...Di Kota Batu pariwisata berbasis masyarakat terakumulasi dalam bentuk desa wisata...Jadi desa wisata merupakan implementasi dari pengembangan pariwisata berbasis masyarakat. Karena dalam pengembangan desa wisata masyarakat yang berperan dan diuntungkan...."

Pemerintah Kota Batu memang bertekad untuk mengembangkan konsep desa wisata di wilayahnya. Tidak heran jika semua desa dan kelurahan yang ada dirintis menjadi desa wisata konsep desa wisata yang tengah digandrungi wisatawan diharapkan bisa meningkatkan derajat kesejahteraan masyarakat pedesaan. Menurut Pak Dedek (Kepada Bagian Program Dinas Pariwisata dan Ekonomi Kreatif Kota Batu) desa wisata sengaja dipilih bukan tanpa pertimbangan. Perhatian pemerintah pada pengembangan obyek wisata modern yang kini sudah cukup berkembang mulai dikurangi dan dialihkan pada pengembangan konsep wisata pedesaan.

\footnotetext{
“ Desa wisata konsepnya bisa diterapkan pada semua desa.tergantung pada kondisi masing-masing..mana potensi desa yang bisa ditawarkan kepada wisatawan bisa pertanian seperti apel, jamur, jeruk, jambu, buah naga, empon-empon (obat tradisional), saur, bunga, dan sebagainya. Pokoknya setiap desa pasti punya komuditas yang menarik, nanti pemerintah membantu mempromosikan kepada wisatawan..."
}

Dari kutipan wawancara tersebut nampak bahwa ada pergeseran strategi pengembangan pariwisata di Kota Batu dari pariwisata massal menjadi pariwisata berwawasan alam. Pariwisata massal memang menguntungkan jika dihitung dari pemasukan dan pajak yang diperoleh. Tetapi mengingat Batu adalah kota yang kecil sehingga memiliki daya tampung terbatas. Konsep wisata massal tidak hanya menghasilkan kemacetan, tetapi juga sampah dan polusi lainnya. Kondisi macet dan polusi jika tidak segera ditanggulangi akan membuat kualitas produk wisata yang dinikmati konsumen/wisatawan akan menurun kualitasnya. Pariwisata massal menguntungkan untuk jangka pendek tetapi tidak berkelanjutan untuk jangka panjang.

Sektor pariwisata yang terus berkembang pesat di Kota Batu membuat Pemerintah Kota Batu terus mencari strategi untuk mewujudkan Kota Batu sebagai sentra pariwisata demi terwujudnya Kota Batu sebagai destinasi pariwisata internasional. Sejumlah desa wisata pun kini telah dibentuk dari 24 desa kelurahan kini sudah ada 12 desa wisata yang dikembangkan sebagai desa wisata tani.

Menurut Dedek :

“...pengembangan pariwisata berbasis masyarakat bisa diwujudkan di desa wisata. Setiap desa nanti akan mendapatkan keuntungan jika wisatawan berkunjung. Misalnya bisa menjual hasil tani dengan harga pantas, menggunakan rumah yang layak sebagai tempat penginapan (home stay) dan menjual aneka makanan dan minuman kepada wisatawan. Kalo dikembangkan desa wisata seluruh desa akan diuntungkan..."

Meski memiliki visi kuat untuk mengembangkan desa wisata, Pemerintah Kota Batu tetap melakukan pengawasan terhadap perkembangan produk wisata khususnya desa wisata. Desa Wisata 
mengembangkan homestay sebagai tempat menginap dengan tujuan agar konsumen mendapat produk akomodasi yang lebih terjangkau namun dengan kualitas yang memandai. Saat ini Dinas Pariwisata dan ekonomi kreatif Kota Batu mulai memperketat pengawasan terhadap perkembangan usaha homestay di Kota Batu yang kini kian menjamur. Para pemilik homestay kini mulai dirangkul dan disarankan untuk segera mendaftarkan usahanya agar memiliki tanda daftar usaha pariwisata atau TDUP. Usaha homestay di Kota Batu berkembang cukup pesat khususnya di daerah-daerah yang dekat dengan lokasi sebuah obyek wisata atau di desa desa yang kini dicanangkan pemerintah sebagai desa wisata.

Di desa Oro oro Ombo yang berdekatan dengan obyek wisata BNS dan Jatim Park 2 kini memiliki homestay sebanyak 70 lebih, sementara menurut data Dinas Pariwisata dan Ekonomi Kreatif Kota Batu jumlah homestay di kota Batu mencapai 300 lebih. Perkembangan ini disikapi oleh Pemerintah Kota Batu dengan memberi pembinaan dan regulasi yang jelas agar usaha homestay lebih terarah dan terciptanya iklim usaha yang sehat termasuk dengan mewajibkan semua pemilik homestay untuk mendaftarkan usahanya agar memiliki tanda daftar usaha pariwisata atau TDUP seperti yang diamanatkan UU No 10 tahun 2009 tentang kepariwisataan dimana setiap pemilik usaha homestay wajib memiliki TDUP. Disinyalir saat ini belum ada homestay di Kota Batu yang memiliki TDUP padahal untuk mengurusnya gratis karenanya melalui kegiatan pelatihan manajemen homestay di Riverstone Hotel and Cottage yang diikuti oleh para pemilik homestay ini pihak dinas juga memanfaatkannya untuk mensosialisasikan kewajiban mengurus TDUP. Terdaftarnya homestay di instansi pemerintah akan memudahkan Pemerintah untuk mengidentifikasi berapa jumlah homestay di kota Batu serta memudahkan untuk melakukan pembinaan. Bagi pemilik homestay juga diuntungkan jika nantinya ada bantuan dari pemerintah maka hanya mereka yang akan mendapatkan bantuan tersebut termasuk saat ada event besar di Kota Batu hanya mereka yang akan dilibatkan menampung tamu Pemerintah Kota Batu.

Untuk mendukung keberadaan desa wisata Dinas Pariwisata dan Ekonomi Kreatif Kota Batu membantu mengembangkan pasar dan melakukan promosi. Salah satu strategi yang dilakukan adalah menggelar kegiatan Batu Travel Mart atau BTM yaitu sebuah ajang untuk mempertemukan para pelaku industri wisata atau seller dengan pemilik agen perjalanan wisata atau buyer guna terjalinnya kerjasama antar kedua pihak di bidang pariwisata. Batu Travel Mart atau BTM digelar di Hotel Kusuma Agro Wisata pada 26-28 November 2013. Sebagai pelaksana kegiatan Dinas Pariwisata melibatkan Batu Professional Tourism Association (BAPTA) yang merupakan kumpulan komunitas pemandu wisata, komunitas agen wisata dan komunitas pemilik travel wisata di Kota Batu. BTM sendiri merupakan ajang untuk mempertemukan para pelaku industri wisata atau seller dan pemilik agen perjalanan atau buyer melalui kegiatan ini diharapkan terjadi kerjasama di mana ke depannya para buyer bisa membawa rombongan wisatawan ke Kota Batu.

Sesuai dengan tagline atau jargonnya yakni "East Java Starts Here" yang artinya "Jawa Timur dimulai dari sini" diharapkan setiap wisatawan yang akan berkunjung ke obyek manapun di Jawa Timur terlebih dulu mampir ke Kota Batu dan baru melanjutkan ke obyek wisata yang lain. Pada tahun 2013 Pemerintah Kota Batu mengusung tema "Eco and Culture Tourism" atau "pariwisata alami dan budaya". Sekitar 130 buyer yang datang ke BTM di antaranya dari Sumatera, Medan, Lampung, Tarakan Banjarmasin, Pontianak, Jakarta, Bandung, Jogjakarta, Bali, Manado, Makassar, Mimika dan perwakilan dari Malaysia dan Singapura.

Para buyer yang hadir dalam acara dikenalkan dengan wisata alami dan budaya yang ada di desa-desa wisata di Kota Batu. Selain desa yang memiliki agrowisata yang sudah dikenal (seperti Bumiaji, Tulungrejo, Sidomulyo) ada tiga desa wisata yang akan dituju yakni Dusun Kungkuk, Desa Punten, Desa Oro Oro Ombo dan Desa Wisata Temas. Masing masing desa memiliki potensi sendiri-sendiri yang berbeda satu sama lain. Dusun Kungkuk menonjolkan keindahan alam sebagai atraksi wisata. Sementara di Oro oro Ombo dikembangkan perkampungan homestay, budidaya ulat Hongkong dan kesenian pencak silat sebagai atraksi wisata. Sedangkan di Desa Wisata Temas, ada wisata petik sayur dan hiburan atraksi bantengan. Semua atraksi yang ditampilkan memberikan pengalaman tersendiri kepada konsumen baik pengalaman secara sosial dan budaya. Wisatawan yang datang berkunjung ke 
masing-masing desa wisata akan memperoleh kesan mendalam tentang kehidupan masarakat yang berbeda dengan kehidupan di tempat asal wisatawan.

Kebijakan Pemerintah Kota Batu untuk mendukung pelaksanaan Community Based Tourism (CBT) dimulai sejak tahun 2007 ketika Kota Batu mengubah visi daerah dari "Batu Kota Agropolitan" menjadi "Batu Sebagai Sentra Pariwisata Berbasis Pertanian Didukung Oleh SDM, SDA, dan SDB serta Pemerintahan yang Kreatif, Inovatif dan Bersih bagi Seluruh Rakyat, yang Dijiwai Keimanan dan Ketakwaan Kepada Tuhan yang Maha Esa”. Dalam perubahan visi tersebut terkandung makna pengembangan Kota Batu secara internal menjadi lebih global yaitu Kota Batu sebagai sentra/pusat pariwisata bagi wilayah di sekitarnya, yaitu Jawa Timur dan bahkan secara nasional, yang mampu memberikan kontribusi ke tingkat internal dan eksternal. Dari visi tersebut juga terkandung makna adanya penguatan peran industri pariwisata dalam pembangunan Kota Batu.

Terdapat perubahan yang signifikan dalam visi tersebut, yang hal ini akan memengaruhi secara umum pengembangan kebijakan pembangunan pariwisata yaitu dari Kota Wisata menjadi Sentra Wisata. Sebagai kota wisata, Kota Batu sudah sejak lama menjadi salah satu ikon wisata di Jawa Timur. Bahkan sejak zaman Belanda, Kota Batu mendapat julukan sebagai De Kleine Stetzerland atau Swiss kecil di Pulau Jawa (http://batukota.go.id). Oleh karena itu, pengembangan pembangunan pariwisata ditujukan pada pengembangan Kota Batu sebagai tujuan wisata. Hal ini berbeda dengan visi baru Kota Batu yaitu sebagai sentra wisata yang dapat dimaknai Kota Batu merupakan pusat wisata di Jawa Timur/Nasional. Terdapat asumsi bahwa di Kota Batu wisatawan/pengunjung dapat menemukan berbagai jenis atraksi wisata baik yang bersifat alam, artifisial (buatan), maupun budaya dengan tetap berbasis pada pengembangan sektor pertanian. Dengan demikian, pengembangan sentra wisata dilakukan dengan memanfaatkan sektor pertanian yang didukung oleh kondisi geografis (kondisi tanah, tingkat kesuburan tanah, topografi, iklim, kekayaan flora/fauna, dan panorama alam yang indah), yang semakin memperkuat daya tarik pariwisata.

Kota Batu merupakan wilayah dengan potensi kegiatan pertanian terutama pertanian tanaman pangan dan hortikultura. Sektor kegiatan industri kecil dan menengah, pariwisata dan perdagangan merupakan kegiatan-kegiatan yang direncanakan dan didorong lebih intensif. Wilayah strategis yang merupakan lokasi rencana pengembangan pusat-pusat kegiatan Kota Batu terdapat di tempat-tempat berikut: 1) Kecamatan Kota Batu meliputi Kelurahan Kota Batu, Kelurahan Ngaglik, Kelurahan Sisir, Kelurahan Temas, Kelurahan Songgokerto, Desa Pesanggrahan, Desa Sumberejo, Desa Sidomulyo, dan Desa Oro-oro ombo, 2) Kecamatan Junrejo meliputi Desa Beji, Desa Junrejo, Desa Pendem, Desa Mojorejo, dan Desa Dadaprejo, dan 3) Kecamatan Bumiaji meliputi Desa Bumiaji, Desa Punten, Desa Giripurno, Desa Tlengkung dan Desa Tulungrejo.

Pusat-pusat kegiatan memiliki kegiatan utama dengan susunan fungsi kawasan sebagai tempat perumahan, pemusatan dan distribusi pelayanan jasa pemerintahan, pelayanan sosial, dan kegiatan ekonomi. Pengembangan pusat kegiatan Kota Batu terdiri dari rencana pengembangan kegiatan sektor perdagangan dan jasa, rencana pengembangan sektor perkantoran, rencana pengembangan sektor perumahan, dan rencana pengembangan sektor pariwisata.

Kebijakan pengembangan agrowisata merupakan salah satu prioritas pengembangan pariwisata di Kota Batu mengingat agrowisata merupakan potensi yang telah dikenal sejak zaman penjajahan Belanda. Pemerintah terus mengupayakan agar meningkatkan, memperluas, dan mengembangkan atraksi wisata agro (agrowisata) yang ada di Kota Batu. Kebijakan pengembangan kawasan pariwisata di Kota Batu berupa pengembangan kawasan dengan luas tertentu untuk memenuhi kebutuhan pariwisata, termasuk pengusahaan objek dan daya tarik wisata serta usaha-usaha yang terkait dengannya. Kawasan peruntukan pariwisata merupakan kawasan yang didominasi oleh fungsi kepariwisataan. Kawasan ini mencakup sebagian areal dalam kawasan lindung atau kawasan budidaya lainnya.

Pengelolaan kawasan pariwisata di Kota Batu diatur dan dilaksanakan dengan memperhatikan aspekaspek berikut ini: (1) Kemampuan untuk mendorong dan meningkatkan perkembangan kehidupan 
ekonomi dan sosial budaya, di mana kawasan wisata harus mampu menggerakkan perekonomian lokal dan meningkatkan peran sosial budaya masyarakat; (2) tidak bertentangan dengan nilai-nilai agama, adat istiadat, serta pandangan dan nilai-nilai yang hidup dalam masyarakat; (3) menjaga kelestarian budaya dan mutu lingkungan hidup; dan (4) memperhatikan kelangsungan keberlanjutan usaha pariwisata.

Salah satu konsep yang berpotensi untuk dikembangkan menjadi objek wisata Desa adalah Living with People, wisatawan tinggal menyatu dengan penduduk beserta tata cara dan tradisi yang berlaku di masyarakat. Konsep wisata desa ini merupakan pengembangan dari kegiatan agrowisata petik apel/panen yang telah ada agar wisatawan punya banyak pilihan untuk mengkonsumsi atraksi wisata. Bagi yang memiliki waktu singkat bisa mengikuti petik apel, sedangkan yang ingin waktu yang lebih lama dapat memilih living with people. Selain itu, dengan durasi kunjungan lebih lama di agrowisata diharapkan akan meningkatkan belanja wisatawan yang berdampak positif bagi perekonomian masyarakat setempat.

Beberapa potensi yang sudah diindentifikasi sebagai tujuan wisata desa dengan konsep "living with people" antara lain adalah garden homestay di Desa Sidomulyo, Desa Punten, Desa Gunungsari, dan Desa Tulungrejo dengan tema kegiatan wisata "living with flowers farmers". Atraksi wisata yang disuguhkan adalah beraneka ragamnya pemandangan hijau dan warna warninya tanaman hias dan bunga di sepanjang Jalan Bukit Berbunga yang terkenal sebagai pusat penjualan bunga di Kota Batu dengan potensi bunga potong-gladiol, mawar, krisan, anthurium dan kebun percobaan pembibitan bunga. Berkaitan dengan tema "living with flowers farmers", atraksi wisata yang disuguhkan oleh desa wisata Desa Sidomulyo, Desa Punten, Desa Gunungsari dan Desa Tulungrejo adalah partisipasi aktif wisatawan seperti mengamati, menanam, dan memetik hasil tanaman hias. Dalam mendukung hal tersebut dikembangkan koridor penjual bunga yang terdapat di sepanjang Jalan Bukit Berbunga Desa Sidomulyo agar memberikan kemudahan pelayanan dan kenyamanan wisatawan yang akan berbelanja tanaman hias dan bunga.

Selain garden homestay konsep "living with people" juga dikembangkan di kawasan Agrowisata khususnya hortikultura buah apel dan jeruk. Hortikultura apel di Kota Batu memusat di Desa Bumiaji Kecamatan Bumiaji, dan Desa Tulungrejo. Hortikultura jeruk memusat di Tlengkung dan Oro-Oro Ombo dengan terdapatnya pusat penelitian jeruk Balejestro dan lahan pertanian hortikultura jeruk di Desa Bumiaji. Seperti halnya garden homestay, maka di lokasi wisata akan dikembangkan atraksi wisata berupa integrasinya wisatawan dengan masyarakat yaitu berkegiatan mengamati, menanam serta memetik apel dan jeruk. Kegiatan wisata ini dapat menambah wawasan wisatawan mengenai proses penanaman buah apel dan jeruk serta cara memanennya. Rencana pengembangan lokasi wisata desa berdaya tarik wisata diarahkan menjadi satu linkage system dengan daya tarik wisata lainnya.

Pengembangan agrowisata didukung oleh kawasan stretegis wisata perkotaan dalam suatu rangkaian pengembangan. Atraksi wisata perkotaan yang dikembangkan adalah menikmati bangunan tematik, meliputi bangunan-bangunan kuno peninggalan dari Belanda di Jalan Panglima Sudirman dan Jalan WR. Supratman, bangunan peribadatan seperti Gereja Katolik di Jalan Panglima Sudirman, Gereja GPIB di Jalan Raya Trunojoyo, wisata jalan kaki yang didukung dengan Pedestrian ways dikembangkan di sekitar alun-alun Kota Batu, kawasan festival road di Ngaglik dan plaza di boulevard Ngaglik. Jalur pejalan kaki ini diperuntukkan untuk mempermudah dan memberikan kenyamanan bagi wisatawan ketika melakukan kegiatan wisata seperti berbelanja dan menyaksikan atraksi wisata yang disajikan seperti kegiatan Kota Batu Flora Festival. Wisata belanja dan kuliner direncanakan menjadi pendukung daya tarik wisata di Kota Batu. Beraneka ragam makanan khas Kota Batu dapat dijumpai di Kota Batu seperti sop buntut, gurame bakar, sate kelinci, bebek kuali, ayam goreng dan rawon, sedangkan untuk jajan malam kawasan kaki lima dapat dijumpai menu masakan pecel lele, ayam goreng, bebek goreng, usus goreng serta wader goreng. Wisata belanja dan kuliner direncanakan untuk dikembangkan di Desa Oro-oro Ombo. 


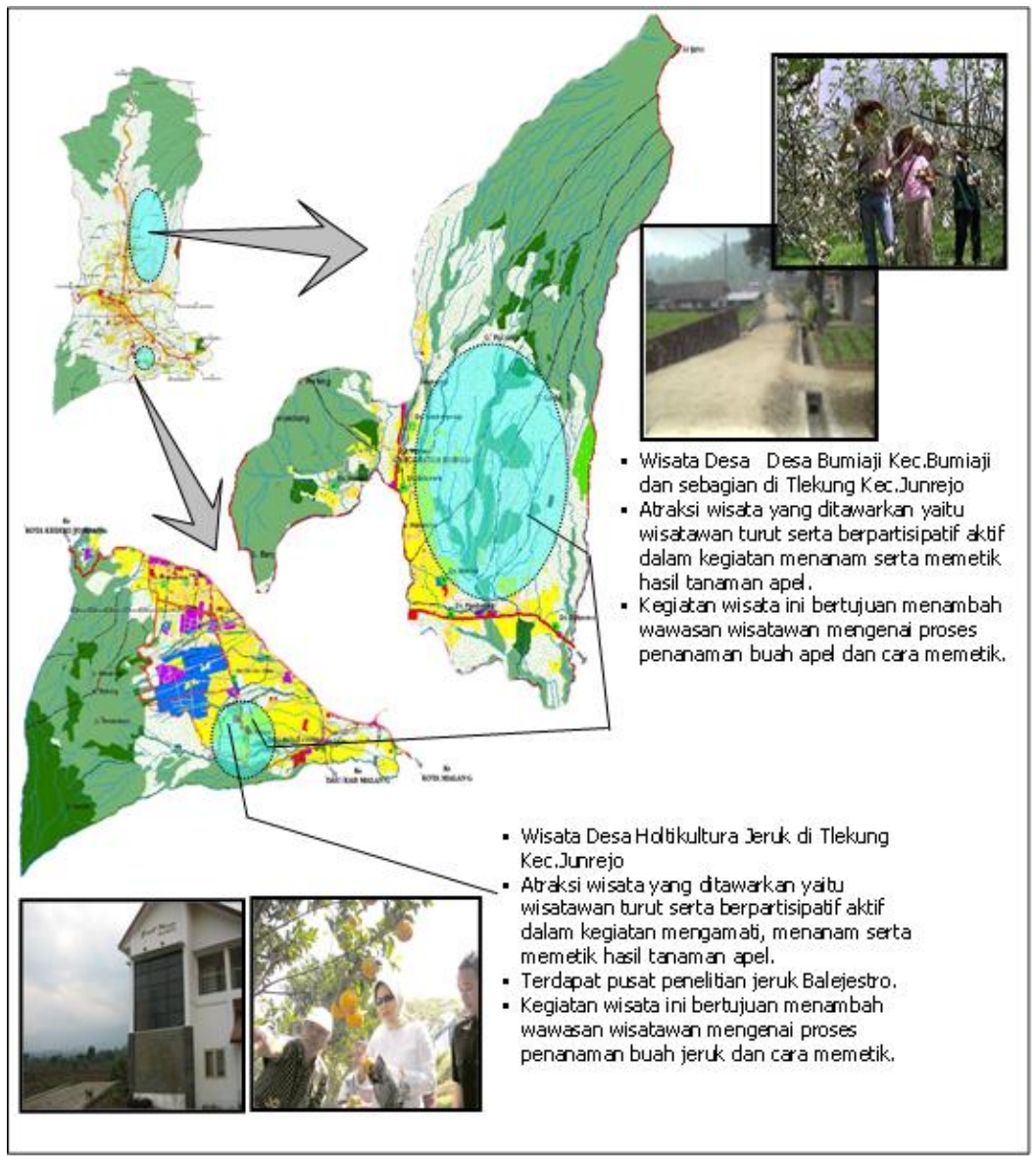

Gambar 5.

Rencana pengembangan agrowisata dan desa wisata hortikultura apel dan jeruk (Sumber: RTRW Kota Batu 2009-2029).

Dalam mengimplementasikan pendekatan CBT di Kota Batu juga mengalami beberapa kendala baik yang bersumber dari internet pemerintah maupun dari masyarakat umum. Menurut UN-WTO dalam Pitana (2009:113) peran pemerintah dalam menentukan kebijakan pariwisata sangat strategis dan bertanggung jawab terhadap beberapa hal, salah satunya adalah "menyediakan dan memfasilitasi kebutuhan legislasi, regulasi, dan kontrol yang diterapkan dalam pariwisata, perlindungan lingkungan, dan pelestarian budaya". Dengan demikian pembangunan pariwisata diperlukan pemahaman baik dari pemerintah selaku regulator maupun dari masyarakat. Pemerintah tentu harus memperhatikan dan memastikan bahwa pembangunan pariwisata itu akan mampu memberikan keuntungan sekaligus menekan biaya sosial ekonomi serta dampak lingkungan sekecil mungkin. Idealnya masyarakat harus mampu menyesuaikan dengan kebijakan dan regulasi dari pemerintah.

Dalam pelaksanaan pengembangan pariwisata berbasis masarakat di Kota Batu terdapat beberapa hambatan yang dapat mengurangi optimalisasi pelaksanaan pembangunan pariwisata. 1) berkaitan dengan kualitas SDM di lingkungan pemerintah kota Batu. Secara umum pemegang keputusan di lingkungan Pemerintah Kota Batu tidak memiliki latar belakang pendidikan pariwisata sehingga mengalami kesulitan untuk merancang program pembangunan berbasis masarakat. Pada umumnya program yang dilakukan diadopsi dari daerah lain atau dikembangkan berdasar pemahaman dan asumsi individu pemegang keputusan, karena kurang matang dalam merancang program pelaksanaannya tidak bisa maksimal. Contoh kegiatan pelatihan pemandu wisata yang diikuti oleh anggota masyarakat (karang taruna atau tokoh masyarakat) menggunakan metode yang sama dengan pelatihan guide profesional sehingga hasilnya kurang menggembirakan. 
Masyarakat yang memang tidak memiliki pengetahuan dasar khususnya bahasa asing memang harus dilatih sedikit demi sedikit dengan metode khusus yang sesuai dengan kemampuan peserta. Pendekatan yang digunakan perlu mempertimbangkan kondisi masyarakat lokal. 2) SDM pemerintah kurang kreatif dalam merancang program dan terkesan dipaksakan. Misalnya pelatihan pengembangan industri lokal seringkali tidak melalui proses assesment dan langsung diputuskan tanpa meminta pendapat dari masyarakat. Akibatnya pelatihan yang berlangsung sering tidak tetap sasaran. Para pelaksana (pemerintah) harus fleksibel dan mau belajar dari pengalaman serta mencoba beberapa metode dalam pemberdayaan masyarakat. 3) Kurangnya kepercayaan pemerintah kepada masyarakat lokal. Para pelaksana (pendamping dan aparat pemerintah) idealnya harus berpihak kepada masyarakat. Mereka harus percaya kepada kemampuan masyarakat dan dapat membagi pengetahuannya. Masyarakat sering dianggap tidak mampu dan pasif menunggu program pemerintah saja, namun yang terjadi di Kota Batu justru sebaliknya.

Di beberapa Desa (misalnya di Desa Bumiaji dan Tulungrejo) masyarakat memiliki kesadaran untuk mengembangkan industri pariwisata secara mandiri. Masyarakat memiliki kepekaan mengidentifikasi peluang pasar yang ada dan menangkap peluang dengan menawarkan produk wisata, namun memang masih banyak Desa yang masih bergantung pada program pmerintah dalam mengembangkan potensinya. 4) Pemerintah kurang mampu memetakan kondisi sosial masyarakat berkaitan dengan sistem pengambilan keputusan dalam internal masyarakat sehingga kurang bisa melakukan intervensi pada semua komponen masyarakat. Setiap masyarakat memiliki karakteristik unik yang harus dipahami pemerintah sebelum melakukan intervensi program.

Di Desa Bumiaji Kecamatan Bumiaji misalnya masyarakat digerakkan oleh actor komunitas yaitu guru dan tokoh masyarakat. Di tempat lain yaitu Desa Tulungrejo aktor komunitas yang berperan adalah kelompok tani. Pemerintah lebih mudah menggerakkan masyarakat dengan cara melibatkan actor komunitas ini dalam proses pengambilan keputusan pembangunan pariwisata. 5) Hambatan lainnya adalah belum mantapnya koordinasi kebijakan antara stakeholder pemerintah, misalnya antara Bappeda dan Dinas Pariwisata dan Ekonomi Kreatif. Pendanaan untuk program pembangunan pariwisata sering tidak menjadi prioritas sebab belum terjadi koordinasi yang mantap. Dana yang dikucurkan SKPD berkaitan dengan program pembangunan pariwisata terbatas dan lebih banyak dialokasikan untuk belanja langsung bukan belanja pembangunan. 6) Pemahaman tentang CBT yang dianggap identik dengan desa wisata sehingga model pengembangan yang dilakukan lebih bersifat fisik daripada filosofik.

Pengembangan semua desa menjadi desa wisata juga merupakan langkah yang masih memerlukan pendampingan kepada masyarakat, khususnya berkaitan dengan manajemen tata kelola yang sederhana namun efektif dan efisien. 7) Rendahnya kemampuan dan keterbatasan wawasan masyarakat dalam hal kepariwisataan merupakan hambatan tersendiri. Salah satu masalah dalam mengembangkan agrowisata adalah belum cukup tersedianya tenaga-tenaga yang cakap, terampil, dan memiliki skill yang tinggi. Dalam masyarakat tertanam anggapan bahwa mereka akan meluangkan waktunya untuk suatu kegiatan apabila mereka merasa bahwa kegiatan tersebut berguna, masyarakat Kota Batu cenderung acuh terhadap kegiatan yang dirasa tidak menguntungkan mereka, termasuk dalam hal kepariwisataan. 8) Partisipasi kurang merata di masyarakat. Tidak secara keseluruhan masyarakat ikut serta, hanya beberapa orang yang memiliki keinginan tinggi. Pengelolaan agrowisata oleh kelompok masayarakat misalnya juga hanya melibatkan sedikit anggota dan komponen masyarakat, sedangkan mayoritas hanya mengikuti saja tanpa memiliki inisiatif. 9) Keterbatasan wilayah Kota Batu sehingga pemerintah mengalami kesulitan untuk mengembangkan sarana dan prasarana pariwisata. 10) Penguasaan teknologi di kalangan pemerintah dan masyarakat yang kurang sehingga belum mengimplementasikan teknologi secara penuh dalam pengembangan pariwisata. 11) Adanya efek pemanasan global membuat iklim berubah, produksi menurun, kualitas produk tidak maksimal sehingga bisa menurunkan kepuasan konsumen. Adanya penggundulan hutan dan penggunaan zat kimia berbahaya secara tidak bijaksana memengaruhi kondisi Kota Batu. Saat ini terjadi kenaikan suhu rata-rata setiap tahun. Jika tidak dicarikan jalan keluar mungkin saja nantinya Batu yang dikenal memiliki iklim yang sejuk menjadi berubah panas dan tidak nyaman utnuk kegiatan pariwisata. 


\section{Simpulan}

Persepsi pemerintah dalam penerapan pariwisata berbasis masyarakat mencerminkan pola pikir dan wawasan individu stakeholder. Di Kota Batu pengembangan pariwisata berbasis masyarakat diidentikkan dengan pengembangan desa wisata di seluruh wilayah Kota Batu. Pemerintah Kota Batu melakukan pengawasan terhadap perkembangan produk wisata khususnya desa wisata. Untuk mendukung keberadaan desa wisata Dinas Pariwisata dan Ekonomi Kreatif Kota Batu membantu mengembangkan pasar dan melakukan promosi.

Hambatan pelaksanaan pembangunan pariwisata berbasis masyarakat berkaitan dengan dua aspek yaitu aspek internal pemerintah dan hambatan eksternal. Hambaran internal pemerintah berkaitan dengan kurangnya pemahaman, wawasan, skill mengembangkan tools pembangunan pariwisata berbasis komunitas (CBT) dan koordinasi yang lemah antar SKPD. Hambatan yang bersifat eksternal adalah rendahnya kemampuan dan keterbatasan wawasan masyarakat dalam hal kepariwisataan, partisipasi kurang merata di masyarakat, keterbatasan wilayah Kota Batu, penguasaan teknologi kurang, dan efek pemanasan global yang memengaruhi iklim produksi dan kualitas produk menurun.

\section{Daftar Pustaka}

Beeton S (2006) Community Development Throught Tourism. Australia: Landlinks Press.

Broadbent J (1988) State as Process: The Effect of Party and Class on Citizen Participation in Japanese Local Government. Sosial Problem 35 (2):131-144.

D'Amore L (1983) Guideline to planning in harmoni with the host community dalam P.E. Murphy (Ed.) Tourism in Canada: Selected Issue and Option. Victoria, BC: University of Victoria.

Demartoto A (2009) Pembangunan Pariwisata Berbasis Masysyarakat. Surakarta: Sebelas Maret University Press.

Denzin NK dan Lincoln Y (2009) Handbook of Qualitatif Research. Yogyakarta: Pustaka Pelajar.

Eadington WR \& Smith VL (1992) Introduction: The Emergence of alternative form of tourism. Dalam. Smith VL \& Eadington WR (Eds.) Tourism Alternatives: Potential and Problems in the Development of Tourism. Philadelphia: University of Pennsylvania Press.

Garrod B (2001) Lokal Partisipation in the Planning and Management of Ecotourism: A Revised Model Approach. Laporan Penelitian. Bristol: University of the West of England.

Gartner W (1996) Tourism Development Principles, Processes, and Policies. New York: Van Nostrand Reinhold.

http://batukota.go.id diakses tanggal 2 Agustus 2014.

Inskeep E (1991) Tourism Planning: An Integrated and Sustainable Development Approach. New York: Van Nostrand Reinhold.

Miles MB \& Huberman AM (1992) Analisis Data Kualitatif: Penerjemah Tjetjep Rohendi R. Jakarta: Universitas Indonesia Press.

Moleong LJ (2005) Metode Penelitian Kualitatif. Bandung: Remaja Rosdakarya.

Murphy PE (1985) Tourism A Community Approach. London and New York: Longman

Pearce PL (1994) Tourism-resident impacts: Examples explanations and emerging solutions. In

Theobald WF (Ed.). Global Tourism. Oxford: Butterworth Heinemann.

Pitana G dan Diarta KS (2009) Pengantar Ilmu Pariwisata. Yogyakarta: Andi.

Timothy DJ (1999) Participatory planning: a view of tourism in Indonesia. Annals of Tourism Research 26 (2):27-40.

Tosun C dan Timothy DJ (2003) Arguments for community participation in the tourism development process. The Journal of Tourism Studies 14 (2):2-15.

Warpani SP dan Warpani I (2007) Pariwisata dalam Tata Ruang Wilayah. Bandung: Penerbit ITB. 